TAPROBANICA, ISSN 1800-427X. June, 2014. Vol. 06, No. 01: pp. 27-31.

(C) Research Center for Climate Change, University of Indonesia, Depok, Indonesia \& Taprobanica Private Limited, Homagama, Sri Lanka http://www.sljol.info/index.php/tapro

\title{
Tall Tales of a Tropical Squirrel
}

\author{
Section Editor: $\quad$ Colin Groves
}

Submitted: 18 December 2013, Accepted: 13 March 2014

\section{Emily Mae Meijaard ${ }^{1}$, Rona Anne Dennis ${ }^{2}$ and Erik Meijaard ${ }^{3,4}$}

\author{
${ }^{1}$ British International School-Jakarta, Jakarta, Indonesia; Email: emily.meijaard@ gmail.com \\ ${ }^{2}$ Country Woods 306, Jakarta, Indonesia \\ ${ }^{3}$ People and Nature Consulting International, Jakarta, Indonesia \\ ${ }^{4}$ School for Archaeology and Anthropology, Australian National University, Canberra, Australia
}

The Tufted Ground Squirrel, Rheithrosciurus macrotis is an endemic of the South East Asian island of Borneo. This species is remarkable in several aspects. Phylogenetic research indicates that its nearest living relatives are a group of South American squirrel species (Mercer \& Roth, 2003). It is unclear how the evolutionary lineage leading to Rheithrosciurus ended up on Borneo without leaving behind any known relatives on either the Asian or North American land masses. The lineage of ancestors of Rheithrosciurus occupying Eurasia is either extinct without known fossil remains or the genus supposedly colonized Borneo in an independent long-distance colonization event (Mercer \& Roth, 2003). More recent studies indicate that the Rheithrosciurus lineage diverged from a group of Palaearctic species of the genus Sciurus as early as 36 million years ago, and colonized Borneo overland from South East Asia (Pečnerová \& Martínková 2012).

Morphologically, Rheithrosciurus is also unusual. Its baculum is similar to that in the genus Sciurus, the squirrels of Eurasia, North and South America, but unlike those found in other South East Asian squirrels (Thomas, 1915; Zahn, 1941), while its longitudinally grooved incisors also remind one of Sciurus (Gray, 1867). Then, there is its club-shaped tail (Gray, 1867). Several early naturalists commented on the spectacularly large tail of Rheithrosciurus (Gray, 1867; Lyon, 1911; Shelford, 1916; Banks, 1931), as exemplified by Banks' (1949) description of the species "run[ning] off swiftly along the ground, usually obscured by a large, bushy, fox-like tail". Banks (1949) further noted that tail of Rheithrosciurus so obscured the animal in flight, "that it is hard to tell what it looks like and to define". Abbott (in Lyon, 1911) thought the large bushy tail carried straight out behind gave an impression of an animal at least the size of a large Silvered Leaf Monkey (Trachypithecus cristatus), which has a head-body length of up $75 \mathrm{~cm}$ compared to $35 \mathrm{~cm}$ in Rheithrosciurus (Payne et al., 1985).

Speculation on the tail function in Rheithrosciurus: Over a number of years, we received 7 camera trap photos of Rheithrosciurus (see Fig. 1A-B), which mostly show the tail in an upright or curved position. To assess the size of the tail of Rheithrosciurus relative to its body, we estimated the approximate tail volume (i.e., the total volume of the tail bush) as a percentage of body volume. This 
indicates an approximate tail volume in Rheithrosciurus of $130 \%$ relative to body volume. We compared this estimate to other mammal species with large, bushy tails by searching for images of large-tailed mammal species on the internet and in mammal identification guides (Table 1). This analysis suggests that Rheithrosciurus has one of the most voluminous tails among all mammals relative to body size. Does this large tail share similar functions with those in other large-tailed mammals (Table 1)?
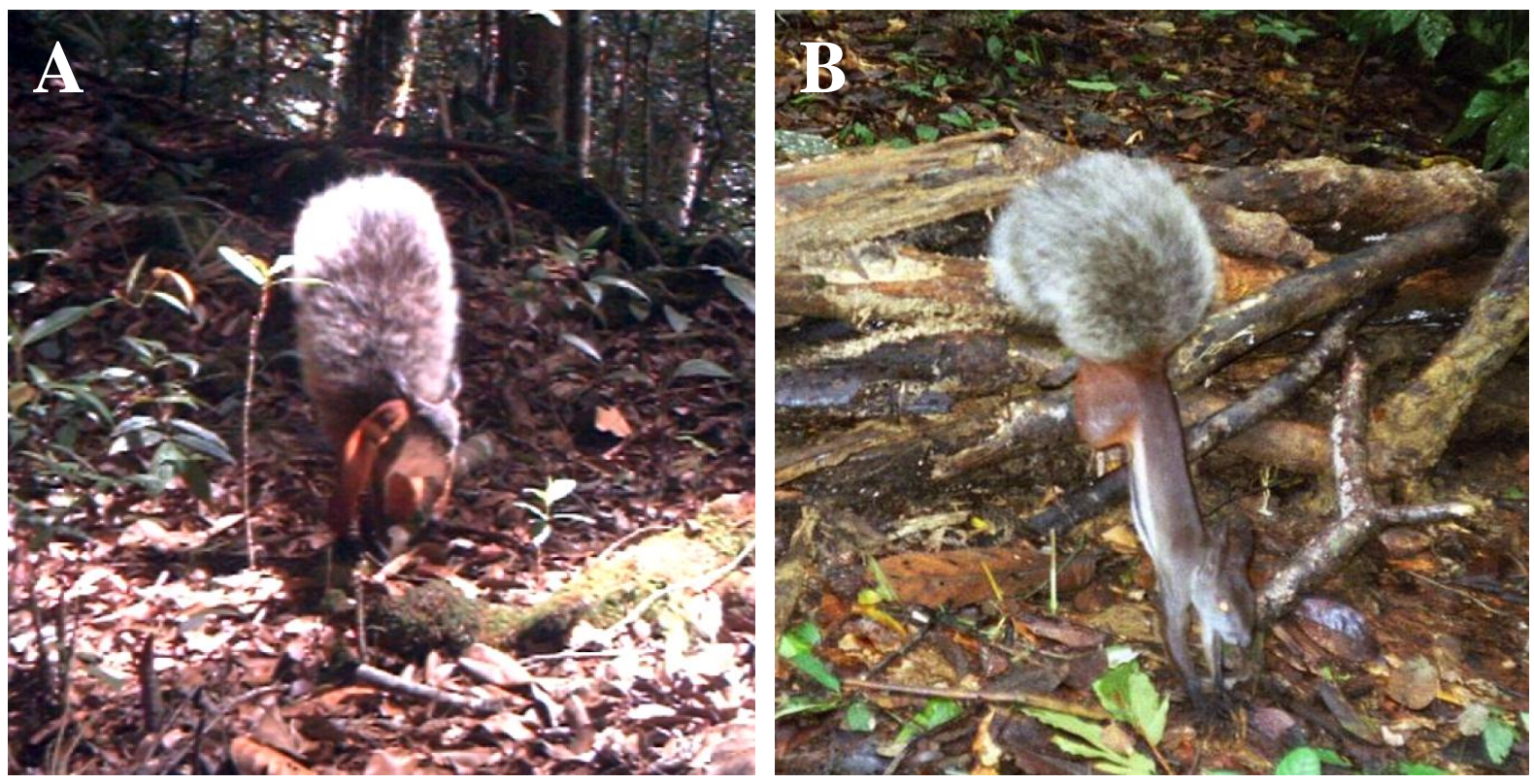

Figure 1: Camera trap photos of Rheithrosciurus macrotis in A, Sarawak, Malaysia (Photo: J. Brodie); B, lowland Dipterocarp forest in East Kalimantan, Indonesia (Photo: D. Augeri).

Table 1: Tail volume estimates relative to body size in selected mammal species with relatively large tail (TV, tail volume; BV, body volume).

\begin{tabular}{|c|c|c|c|}
\hline Species & $\begin{array}{c}\text { TV/BV } \\
(\%)\end{array}$ & Tail function & Reference \\
\hline $\begin{array}{l}\text { Red Squirrel } \\
\text { Sciurus vulgaris }\end{array}$ & 90 & $\begin{array}{l}\text { To accelerate and steer the squirrel when } \\
\text { jumping, keep them balanced, and to keep } \\
\text { them warm when they are sleeping. }\end{array}$ & $\begin{array}{l}\text { Muchlinski \& } \\
\text { Shump, } 1979\end{array}$ \\
\hline $\begin{array}{l}\text { Giant Ant Eater } \\
\text { Myrmecophaga tridactyla }\end{array}$ & 80 & $\begin{array}{l}\text { Acts as disruptive camouflage, and to } \\
\text { conserve body heat especially when sleeping- } \\
\text { they are often found sitting in a way so that } \\
\text { their tail absorbs heat from the sunlight. }\end{array}$ & $\begin{array}{l}\text { Medri \& } \\
\text { Mourão, } 2005\end{array}$ \\
\hline $\begin{array}{l}\text { Red Panda } \\
\text { Ailurus fulgens }\end{array}$ & 40 & $\begin{array}{l}\text { Provides balance and excellent camouflage } \\
\text { against its habitat of moss and lichen covered } \\
\text { trees. }\end{array}$ & Pocock, 1941 \\
\hline $\begin{array}{l}\text { Ring-tailed Cat Bassariscus } \\
\text { astutus }\end{array}$ & 100 & $\begin{array}{l}\text { Provides balance for negotiating narrow } \\
\text { ledges and limbs, even allowing them to } \\
\text { reverse directions by performing a cartwheel. }\end{array}$ & Williams, 2013 \\
\hline $\begin{array}{l}\text { Spotted Skunk } \\
\text { Spilogale gracilis }\end{array}$ & 35 & $\begin{array}{l}\text { Acts as a warning to other creatures before it } \\
\text { secretes a liquid via paired anal subcutaneous } \\
\text { glands. }\end{array}$ & $\begin{array}{l}\text { Kaplan \& } \\
\text { Mead, } 1994\end{array}$ \\
\hline $\begin{array}{l}\text { Aye-aye } \\
\text { Daubentonia madagascariensis }\end{array}$ & 80 & Tail rolled up around body when asleep. & Petter, 1977 \\
\hline $\begin{array}{l}\text { Brush-tailed Phascogale } \\
\text { Phascogale tapoatafa }\end{array}$ & 90 & Can be erected which makes it look larger. & $\begin{array}{l}\text { Menkhorst \& } \\
\text { Knight, } 2001\end{array}$ \\
\hline $\begin{array}{l}\text { Common Striped Possum } \\
\text { Dactylopsila trivirgata }\end{array}$ & 100 & The tail is prehensile. & McKay, 1999 \\
\hline $\begin{array}{l}\text { Squirrel Glider } \\
\text { Petaurus norfolcensis }\end{array}$ & 100 & $\begin{array}{l}\text { Acts as a rudder when gliding. Also used as } \\
\text { another limb as it can curl round branches. }\end{array}$ & $\begin{array}{l}\text { Morcombe \& } \\
\text { Morcombe, } \\
1974\end{array}$ \\
\hline
\end{tabular}


Maintaining a large bushy tail presumably requires some energetic sacrifice, and there must be good evolutionary reasons to justify the expense. In his seminal review of mammalian tails Hickman (1979) discussed various functions of tails: mechanical functions, including inertia, balance, brake, transportation and construction, and defence; behavioural functions, including autocommunication, warning, courtship, and family and group cohesion; and physiological functions, including thermoregulation, food storage and water balance. Although most other tree squirrels of the tribe Sciurini are arboreal (Thorington et al., 2012), Rheithrosciurus is found primarily on the ground or lower tree trunks (Banks, 1931; Payne et al., 1985). A balancing function of the tail for moving along tree branches is therefore not very likely. Mjöberg (1930) speculated that wrapping the bushy tail around its body would keep Rheithrosciurus warm in the montane environments where it occurs. Although mostly found in hilly areas (Payne et al., 1985), Rheithrosciurus is not restricted to montane environments, as attested by the lowland records along the Kendawangan River and in Pamukan Bay (Lyon, 1911). Night temperatures in such tropical lowland sites would not require protection against the cold, although we cannot exclude the possibility that Rheithrosciurus evolved in colder areas and that the tail once had a temperature regulation function. There are no behavioural studies of Rheithrosciurus, and possible roles of its tail in autocommunication, warning, or courtship may exist. Another possibility is that the tail has a defence function. Rheithrosciurus is the largest of the terrestrial squirrels on Borneo, but the only terrestrial squirrel on the island largely feeding on fruit (but see anecdotal stories below) (Payne et al., 1985). Other terrestrial squirrels, such as Three-striped Ground Squirrel Lariscus insignis and Shrew-faced Ground Squirrel Rhinosciurus laticaudatus, feed primarily on invertebrates, and these are on average much smaller than Rheithrosciurus. The second largest Borneo terrestrial squirrel is Everett's Ground Squirrel Dremomys everetti, but it is only 41\% of the body size of Rheithrosciurus (Payne et al., 1985). The Sciurini to which Rheithrosciurus belongs are mostly arboreal frugivores (Thorington et al., 2012). Rheithrosciurus thus appears to have maintained the dietary specialization of the Sciurini, but adapted to more terrestrial habits. A relatively large body size and terrestrial habits requires effective defence against terrestrial predators, such as Sunda Clouded Leopard Neofelis diardi. It may well be that the very large, fluffy tail of Rheithrosciurus is an anti-predator mechanism. In flight, the grey tail, which consists mostly of long fur, obscures the actual body of the animal. This could either confuse a predator in pursuit, or if the predator would pounce on the squirrel it would most likely strike at the tail, which would provide a predator with limited hold. This hypothesis needs to be supported by more detailed behavioural observations before it can be accepted, but it seems the most logical explanation of the Rheithrosciurus's extravagant tail. These considerations might also explain why Rheithrosciurus only survives on Borneo. In the Indo-Malayan Realm, Borneo is the island with the least predator species (Meijaard, 2004). Among the mammalian predators on Borneo, probably only Sunda Clouded Leopard Neofelis diardi, Bay Cat Catopuma badia, or Marbled Cat Pardofelis marmorata could predate on Rheithrosciurus. In other parts of South East Asia, Leopard Panthera pardus, Dhole Cuon alpinus, and a range of other carnivores could significantly heighten predation pressure on a terrestrial species. It might well be that a species that was already vulnerable to terrestrial predation only managed to survive where this predation pressure was lowest, i.e., the low mammalian biomass forests of Borneo (Payne, 1990).

Rheithrosciurus Folklore: We admit that much of the above is speculative, but hope that these ideas will stimulate others to pay closer attention to the morphology and behaviour of this unusual squirrel species. A more detailed study of more camera pictures might provide new insights into tail positioning under different conditions (in flight, at rest etc.). It will not be easy to study this uncommon and elusive species on the ground in dense rainforests where direct observation would be much hampered. Some insights may be obtained from talking to local hunters who may have more frequently observed the species, either at rest or in flight when chased by a hunter or his dogs. In fact, there is a relatively rich animal folklore regarding Rheithrosciurus. People of Borneo have traditionally hunted the species for meat and ornamental use of its tail, among others to adorn machetes (Banks, 1931). Remarkably for a squirrel, forest-dwelling people consider this squirrel to be quite fierce (J. Payne, pers. comm.). One of us (RD) was in fact told a story by a local hunter in northern Central Kalimantan (Indonesian Borneo) of Rheithrosciurus attacking and killing deer to eat the ruminant's stomach contents, liver and heart. On asking how a squirrel could kill a large animal such as a muntjak, Muntiacus muntjak, the response was that the squirrel waits on a low branch for a 
deer to pass below, jumps on its back and bites the jugular vein, whereon the deer bleeds to death. Once dead the squirrel proceeds to disembowel the deer and eat the stomach contents, heart and liver. Dayak hunters sometimes find these disembowelled deer in the forest, none of the flesh eaten, which to them is a clear sign of a squirrel kill. In villages close to the forest edge there were also accounts of the squirrel killing domestic chickens and eating the heart and liver only. Although, the existence of carnivorous squirrels might be a bit hard to believe, the above might fit the description of Banks (1949), who notes that Rheithrosciurus is known as being "wary, difficult to observe and biting fiercely". Also, other squirrels, such as the Giant Squirrel Ratufa affinis are known to actively hunt birds and other vertebrates (R. Ratajszczak, pers. comm.), so we keep an open mind as to what other surprises Rheithrosciurus may reveal on further study. After all, another seemingly unlikely hunter story from Borneo of deer of the genus Tragulus hiding underwater for long periods of time also turned out to be true (Meijaard et al., 2010). Such finds reiterate how little we know about Bornean wildlife, and Rheithrosciurus is only one among many fascinating species on this remarkable island requiring our attention as scientists and conservationists.

\section{Acknowledgements}

We thank Gabriella Fredriksson and Jedediah Brodie for sharing their camera trap photos with us and Aspuri for recounting tales of squirrel behaviour both first and second hand.

\section{Literature Cited}

Banks, E., 1931. A popular account of the mammals of Borneo. Journal of the Malayan Branch of the Asiatic Society, 9: 137.

Banks, E., 1949. Bornean mammals. The Kuching Press, Kuching, Sarawak.

Gray, J. E., 1867. XXXV.- Synopsis of the Asiatic Squirrels (Sciuridæ) in the collection of the British Museum, describing one new genus and some new species. Journal of Natural History Series 3, 20 (118): 270-286.

Hickman, G. C., 1979. The mammalian tail: a review of functions. Mammal Review, 9 (4): 143-157.

Kaplan, J. B. and R. A. Mead, 1994. Seasonal Changes in Testicular Function and Seminal Characteristics of the Male Eastern Spotted Skunk (Spilogale putorius ambarvilus). Journal of Mammalogy, 75 (4): 10131020.

Lyon, M. W., 1911. Mammals collected by Dr. W.L. Abbott on Borneo and some of the small adjacent islands. Proceedings of the United States National Museum, 40 (1809): 53-146.

McKay, G., (ed.)., 1999, Mammals. Weldon Owen Inc., San Francisco.

Medri, Í. M. and G. Mourão, 2005. A brief note on the sleeping habits of the giant anteater Myrmecophaga tridactyla Linnaeus (Xenarthra, Myrmecophagidae). Revista Brasileira de Zoologia, 22: 1213-1215.

Meijaard, E., 2004. The biogeographic history of the Javan leopard Panthera pardus based on a craniometric analysis. Journal of Mammalogy, 85 (2): 302-310.

Meijaard, E., Umilaela, and G. de Silva Wijeyeratne, 2010. Aquatic escape behaviour in mouse-deer provides insight into tragulid evolution. Mammalian Biology, 75: 471-473.

Menkhorst, P. and F. Knight, 2001. A field guide to the mammals of Australia. Oxford University Press, New York.

Mercer, J. M. and V. L. Roth, 2003. The effects of Cenozoic global change on squirrel phylogeny. Science 299 (7 March 2003): 1568-1572.

Mjöberg, E. G., 1930. Forest Life and Adventures in the Malay Archipelago. Allen \& Unwin, London, UK. 
Morcombe, M. and I. Morcombe, 1974. Mammals of Australia. Australian Universities Press, Sydney, Australia.

Muchlinski, A. E. and K. A. Shump Jr., 1979. The Sciurid Tail: A Possible Thermoregulatory Mechanism. Journal of Mammalogy, 60 (3): 652-654.

Payne, J., 1990. Rarity and extinctions of large mammals in Malaysian rainforests. In: Proceedings of the International Conference on Tropical Biodiversity, "In Harmony with Nature", 12-16 June 1990, Kuala Lumpur, Malaysia, Kuala Lumpur, Malaysia: 310-320.

Payne, J., C. M. Francis, and K. Phillipps, 1985. A field guide to the mammals of Borneo. The Sabah Society, Kota Kinabalu, Malaysia.

Pečnerová, P. and N. Martínková, 2012. Evolutionary history of tree squirrels (Rodentia, Sciurini) based on multilocus phylogeny reconstruction. Zoologica Scripta, 41: 211-219.

Petter, J.-J., 1977. The Aye-Aye. In: Prince Rainier III of Monaco and G. H. Bourne (Ed.). Primate Conservation. Academic Press, New York: 37-57.

Pocock, R. I., 1941. Fauna of British India, including Ceylon and Burma. Mammalia. - Volume 2. Taylor and Francis, Ltd., London.

Shelford, R. W. C., 1916. A naturalist in Borneo. Natural History Publications (Borneo), Kota Kinabalu, Malaysia.

Thomas, O., 1915. XXXIV.- - The penis-bone, or "Baculum," as a guide to the classification of certain squirrels. Journal of Natural History Series 8, 15 (88): 383-387.

Thorington, J. R. W., J. L. Koprowski, M. A. Steele, and J. F. Whatton, 2012. Squirrels of the World. John Hopkins University Press, Baltimore, Maryland.

Williams, D. B., 2013. Ringtail Cat (Bassariscus astutus). DesertUSA.com. Retrieved 18 November 2013.

Zahn, W., 1941. Die Riesen-, Streifen- und Spitznasenhörnchen der orientalischen Region. Zeitschrift für Säugetierkunde, 16 (1): 1-182. 